answer each point seriatim, but candidly acknowledge that I am unable to cope with him in the matter of ethics. 1. "Dr. Herbert Tilley names no names." In publishing the cases referred to I had no wish to individualise any institution or its officials. I wrote pro bono publico, feeling that I was doing my duty to my profession and especially to that branch of work to which I devote my time, and for whose good reputation I am solicitous. If, however, Mr. Lennox Browne wishes for the names of the consultants referred to and the patients I shall be perfectly willing to publish them (with their permission and that of the editors) in a coming number of THE LANCET. 2. I am acquainted with most of Mr. Browne's treatises on the subject and have carefully read the last-mentioned of them in the current number of the Liverpool MedicoChirurgical Journal. I am amazed in reading there that he has, amongst 1547 private patients seen within three years, no less than 438 cases (less than 1 in 4 ) of lingual varix. As a result I am more than ever inclined to doubt the value of his observations. 3. Mr. Browne is apparently much perturbed because I only write of three cases. These are only samples. If he prefers a much larger number I can supply them and, if he so desires, the specialists consulted shall be named, with the permissions previously alluded to. 4. Finally, Mr. Browne is obviously incensed that one younger than himself should challenge his observations. May I be allowed to point out, although $\mathrm{Mr}$. Browne may have been working at diseases of the throat longer than I have, that mere seniority is no proof of greater correctness in observation and interpretation, and 1 am deeply sorry that, with all his experience, he has not been able to find a better explanation of the cases than he has done.

I am, Sirs, yours truly,

HeRBerT TILLeY, M.D. Lond.

Welbeck-street, W., Feb. 24th, 1896.

\section{PROFESSIONAL SUBJECTS IN LAY PAPERS.}

\section{To the Editors of THE LANCET.}

SrRs,-With reference to an article which appeared in the Globe of Feb. 18th I have received the enclosed letter from the honorary secretaries of the Medical Society of London which I have their permission to publish. I should feel obliged by your kindly inserting the same in your next issue. I am, Sirs, your obedient servant,

Wimpole-street, W., Feb. 25th, 1896

HERBERT F. WATERHOUSE.

$$
\text { [COPY.] }
$$

The Medical Society of London, 11, Chandos-street, Cavendish-square, W., Feb, 24th, 1896.

Dear Mr. WaterhodSE,-Your note of the 20th inst. was considered by the Council this evening. They regret that your case of bone grafting, shown to the Society on Feb. 10th, should have been commented upon in a non-professional paper, which unfortunately mentioned you also by name. The Council have ascertained that the paragraph appeared entirely without your knowledge and sympathise with you in your annoyance at the occurrence.

$$
\text { Yours truly, }
$$

AMAND RovTH, \} Hon. Secs. to G. R. TERNER, $\}$ Medical Society.

\section{SUBJECTIVE VISUAL SENSATIONS. To the Editors of THE LANCET.}

SIRS,-In accordance with a suggestion of Dr. Gowers, who delivered the Bowman Lecture of the Ophthalmological Society last year upon the Visual Phenomena connected with Epilepsy and Migraine, we are desired by the council of the above society to invite from members of the medical profession any observations they may be willing to record. It would seldom be possible to obtain accurate descriptions or drawings of such sensations from laymen, but it is felt that valuable information might be obtained if members of the profession who are themselves the subjects of migraine would put into writing detailed accounts of the risual symptoms from which they suffer in connexion with an attack. The value of these descriptions would be enhanced if they were accompanied (where possible) by drawings or diagrams of the appearances. It seems likely that the knowledge of the natural history of migraine and allied cerebral conditions night be greatly increased if a large number of such wellrecorded experiences could be gathered together and classified. The nucleus of such a collection has been formed and presented to the society by Dr. Gowers, and the council will be very glad if any of your readers who can do so will help to enlarge it. We shall be glad to receive any communications that may be sent to us.

We are, Sirs, yours faithfully,

S. H. HABERSHoN, 70, Brook-street, W.

J. B. LAWFORD, 99, Harley-street, W.

Feb. 24th, 1896 . Honorary Secretaries of the Ophthalmological

\section{WITH DR. JAMESON'S MEN ON BOARD} THE "HARLECH UASTLE."

\section{To the Ealitors of THE LANCET.}

SIRs,-I have just returned from Natal to Plymouth as medical officer to the Harlech Castle and as medical oficer to Dr. Jameson's men and officers on board the Harlech Castle. I thought it might interest you to have a short account of the sickness amongst them. I enclose a photograph of a few of the wounded. Dr. Jameson's column came on board at Natal on Jan. 24th - viz., Dr. Jameson, 294 men. 23 officers, and 10 women and children; Imperial escort, 18 men, and 2 officers. The men were naturally a very robust body, in age averaging from twenty-three to thirty-five years: but as I am told by the officers and men that after their celebrated march they were confined in Volksruit and Pretoria gaols, where the sanitary arrangements were rery primitive and the stench horrible, Surgeon-Captain C. H. Hale brought on board with him 18 men-11 gunshot wounds, 5 cases of dysentery, and 2 cases of malarial fever-whom he placed under my charge. Three of the wounded were transferred three days later and sent to their homes at the Cape.

Illustration reproduced from a Photograph of Wounded taken on board the "Harlech Castle."

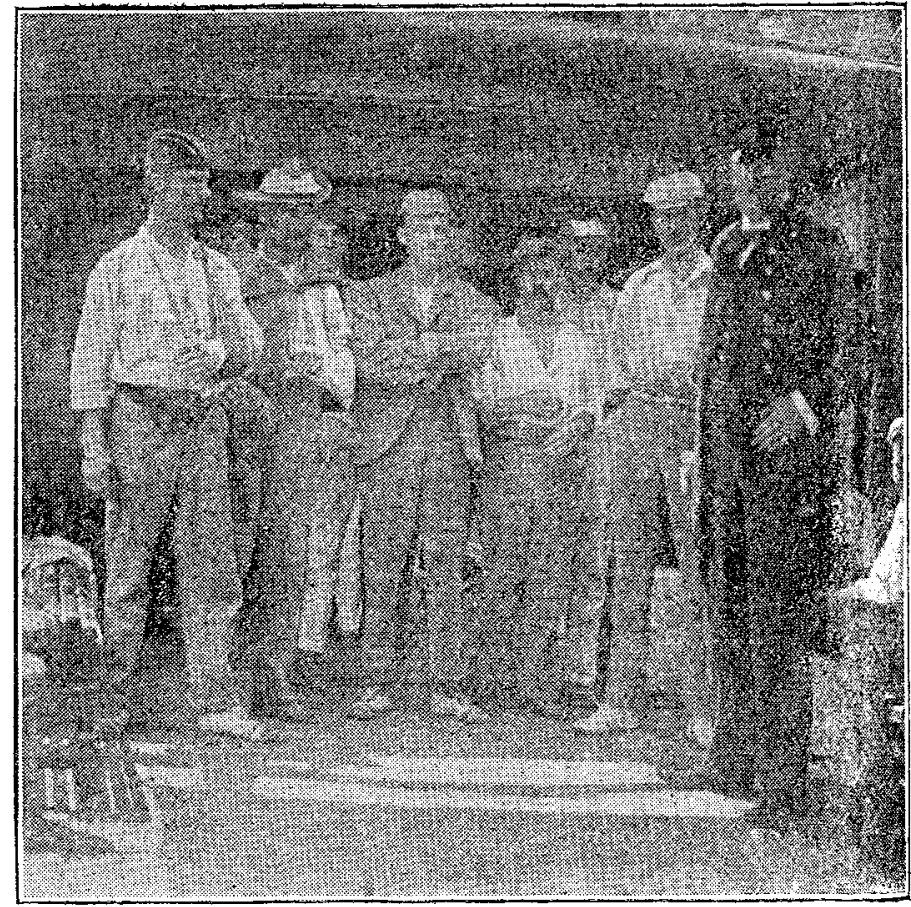

The numbers read from left to right in the illustration.

1. Bullet wound and compound 4 . Bullet wound of side; paresis. fracture of the forearm. $\quad$ 5. Bullet wound in the hall

2. Compound comminuted frac- 6. Bullet wound of arm and she. ture of the forearm.

The wounds all progressed very farourably, being oressed with antiseptic precautions; the cases of dysentery rrogressed favourably, as did also the malaria, but typloid firer broke out on Jan 30 th.

A trooper came to see me at about the end of the second week of the disease. I understand from his comrades that tor some three months he had been in a weak state of hititi. but did not care to ask for medical attention. Wher be applied to me I immediately isolated him, disinfectel Lis cabin, and took the usual precautions. I then asked Mr. E. C F. Garraway, Mr. W. H. F. Farmer, and Surgeon-Carain Seton Hamilton, who had been with them in the fielu, if the would kindly meet me to see if anything further cori done, but in spite of all our efforts he sank and died at anut the end of the third week. His case was complicatea witi 